\title{
Samorząd terytorialny w Brazylii i Polsce - analiza porównawcza
}

\author{
\# samorząd \# samorząd terytorialny \# porównanie \\ \# konstytucja \# gmina \# stan \# kompetencje \\ \# Poland \# Brazil \# council \# local government \# comparison \\ \# constitution \# community \# state \# competence
}

Celem publikacji jest przybliżenie funkcjonowania samorządu terytorialnego w Federacyjnej Republice Brazylii oraz porównanie go z samorządem polskim. Kluczowym punktem dla zrozumienia samorządu brazylijskiego w jego obecnym kształcie jest poznanie zarówno historii, jak i cech państwa, dlatego takie informacje znajdują się na początku niniejszego opracowania. Swoją analizę oparłam w dużej mierze na przepisach konstytucyjnych, ponieważ konstytucje państw Ameryki Południowej cechują się obszernymi regulacjami, z których można zaczerpnąć nie tylko podstawowe informacje.

The aim of the publication is to present the functioning of territorial self-government in the Federative Republic of Brazil and to compare it with that in Poland. A key point to understanding Brazilian local government is to know the history. I based on constitutional provisions because the constitutions of Latin American countries have large regulations from which much can be drawn.

Miasto. Pamięć i Przyszłość 3/2 (2018) ISSN 2543-621X

\section{OPEN ACCESS}

Citation: Sucharska M., Samorząd terytorialny w Brazylii i Polsce - analiza porównawcza, "Miasto. Pamięć i Przyszłość", 3/1 (2018).

https://doi.org/10.26774/mpp.77

Editor: Jerzy Korczak

Received: October, 2018

Accepted: December, 2018

Published: December, 2018

Copyright: @ Ośrodek „Pamięć i Przyszłośćc This is an open access article distributed under the terms of the Creative Commons Attribution-ShareAlike Licence, which permits unrestricted use, distribution, and reproduction in any medium, provided the original author and source are credited, with indications if any changes are made. All derivative works must be licensed under the same licence. 
Martyna Sucharska - studentka II roku studiów magisterskich na kierunku administracja na Wydziale Prawa, Administracji i Ekonomii Uniwersytetu Wrocławskiego; wiceprezes Studenckiego Koła Naukowego Prawa Latynoamerykańskiego 


\section{Krótko o historii Brazylii}

Mówiąc o historii samorządu terytorialnego Republiki Federacyjnej Brazylii, zasadnym wydaje się zbadanie zarówno podziału terytorialnego, jak i samego samorządu. Poznając organy i instytucje, warto wiedzieć, na jakim terenie funkcjonowały.

Dla Europejczyków początki Brazylii (nazywanej pierwotnie Pindoramą) sięgają kwietnia 1500 r., kiedy to Pedro Álvares Cabral, portugalski żeglarz zmierzający w kierunku Przylądka Dobrej Nadziei, odkrył Brazylię. Rok później Brazylia stanowiła już kolonię portugalską, będącą zapleczem bogactw i surowców naturalnych. W czasach kolonialnych obszar Brazylii podzielony był na kapitanie, czyli dziedziczne obszary władane przez przedstawicieli szlachty portugalskiej, położone równoleżnikowo w głąb lądu'. Z związku z powyższym można w tym kontekście mówić jedynie o pewnym podziale terytorium, a nie samym samorządzie.

W 1821 r. zwołane w Rio de Janeiro Zgromadzenie Narodowe uchwaliło oddzielenie Brazylii od Portugalii, a w 1822 r. powstało niezależne od Korony Portugalskiej Cesarstwo, kiedy to 12 października Dom Pedro przyjąłtytuł cesarza. Kraj podzielono na prowincje, a na czele cesarstwa stanął dotychczasowy regent i dziedzic korony portugalskiej Pedro I. Na pewno mówimy o samorządzie w kontekście wspomnianych czasów regenckich, tj. lat 1831-1834, kiedy znowelizowano ówczesną konstytucję, dodając do niej akt dodatkowy, tworzący Zgromadzenia Prowincjonalne i nadający im realne kompetencje.

\section{Brazylia - położenie i podział terytorialny}

Federacyjna Republika Brazylii (port. República Federativa do Brasil) jest jednym z największych państw świata, obejmuje bowiem niemal połowę Ameryki Południowej. Rozciąga się wzdłuż wybrzeża atlantyckiego oraz Amazonki. Liczy ponad 200 mln mieszkańców, a największe aglomeracje to São Paulo i Rio de Janeiro. Na południu dominuje ludność pochodzenia europejskiego (Portugalczycy, Włosi, Niemcy,
Miasto. Pamięć i Przyszłość 3/2 (2018) ISSN 2543-621X
1. Więcej na ten temat: https://histmag.org/Historia-Brazylii-10-dat-ktore-powinienes-znac-9603 [dostęp: 07.04.2018]. 


\section{Rys. 1 Koronacja Pedro I na Cesarza Brazylii}

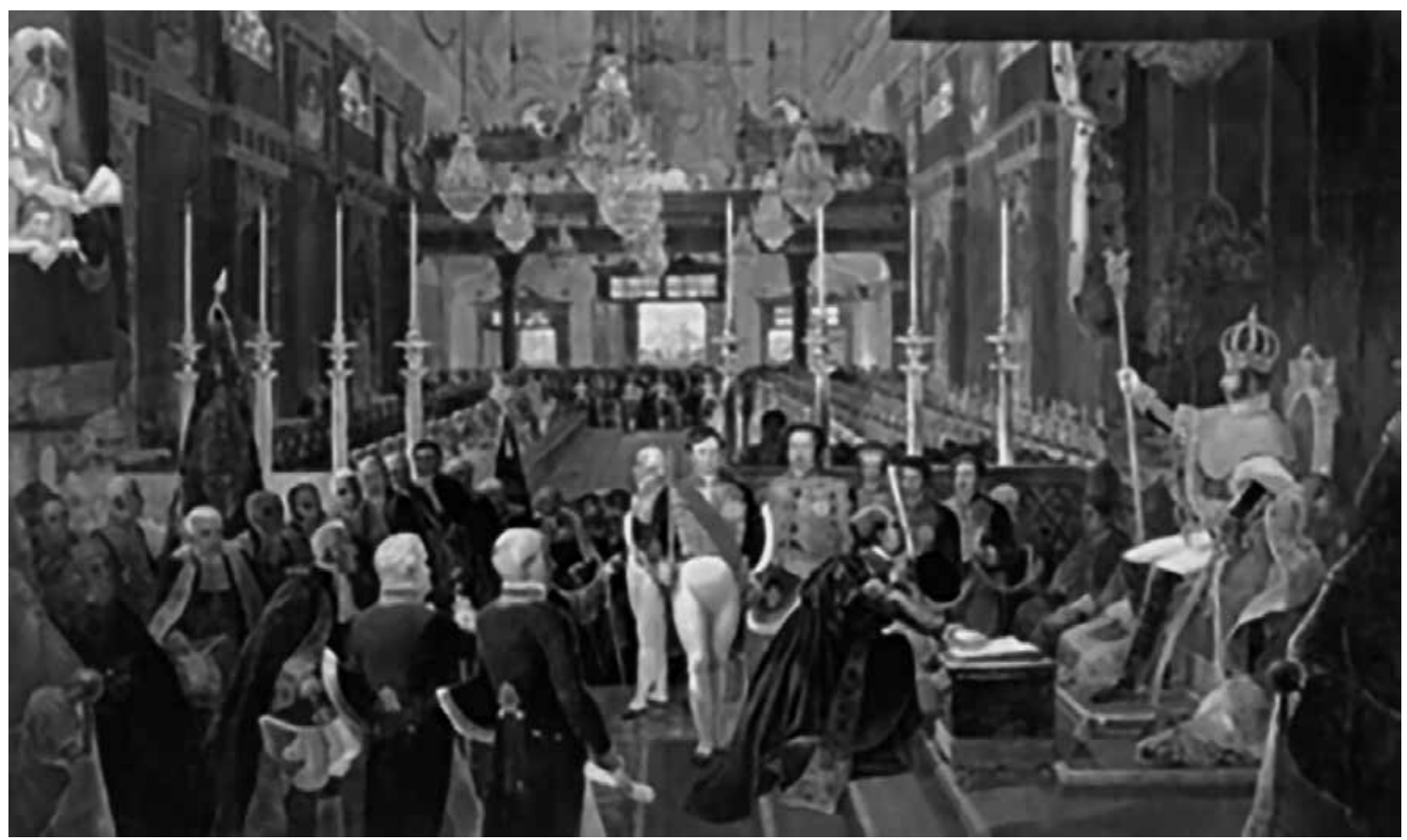

Żródło: dezenovevinte.net

Polacy²), na wschodzie - Mulaci, a na północnym zachodzie - Indianie. Brazylia jest jedynym krajem na świecie, przez który przebiega zarówno równik, jak i zwrotnik Koziorożca. Na jej terytorium można wyróżnić trzy duże krainy geograficzne: część Wyżyny Gujańskiej, Wyżynę Brazylijską n oraz Nizinę Amazonki nazywaną

2. W Brazylii mieszka wiele osób polskiego pochodzenia. Brazylijska Polonia liczy sobie, wg różnych źródeł, od 150 tys. do 800 tys. osób. Największe jej skupiska znajdują się w południowych stanach: Paraná według danych polonijnych 1500 tys., Santa Catarina - około 280 tys., Rio Grande do Sul - 300 tys. i Sao Paulo. Więcej o pierwszych osadnikach: http://natemat.pl/176391,nawet-3-mln-mieszkancow-tego-regionu-w-brazylii-ma-polskie-korzenie-parana-mala-polska-za-oceanem [dostęp: 07.04.2018].

3. Szczegółowy opis każdego stanu: https://www.brazil.org.za/states-of-brazil.html albo http://caipiroska.pl/category/stany-brazylii/ [dostęp: 07.04.2018].

4. Więcej o dystrykcie: http://www.df.gov.br/ [dostęp: 07.04.2018].
Amazonią. Długość wybrzeża Brazylii wynosi 7491 km. Graniczy z dziesięcioma państwami: Argentyną, Boliwią, Gujaną Francuską, Gujaną, Kolumbią, Paragwajem, Peru, Surinamem, Urugwajem oraz Wenezuelą.

Brazylia to republika związkowa podzielona na 26 stanów (port. estados)3, tworzących tzw. unię i 1 dystrykt federalny4 (nie mający formalnego charakteru) - miasto Brasília, będące zarazem stolicą kraju. Stany dzielą się na gminy i mogą łączyć się ze sobą, dzielić na mniejsze części bądź odłączać części terytorium w celu przyłączenia do innych stanów lub utworzenia Miasto. Pamięć i Przyszłość 3/2 (2018) ISSN 2543-621X 
Mapa 1. Podział terytorialny Brazylii.

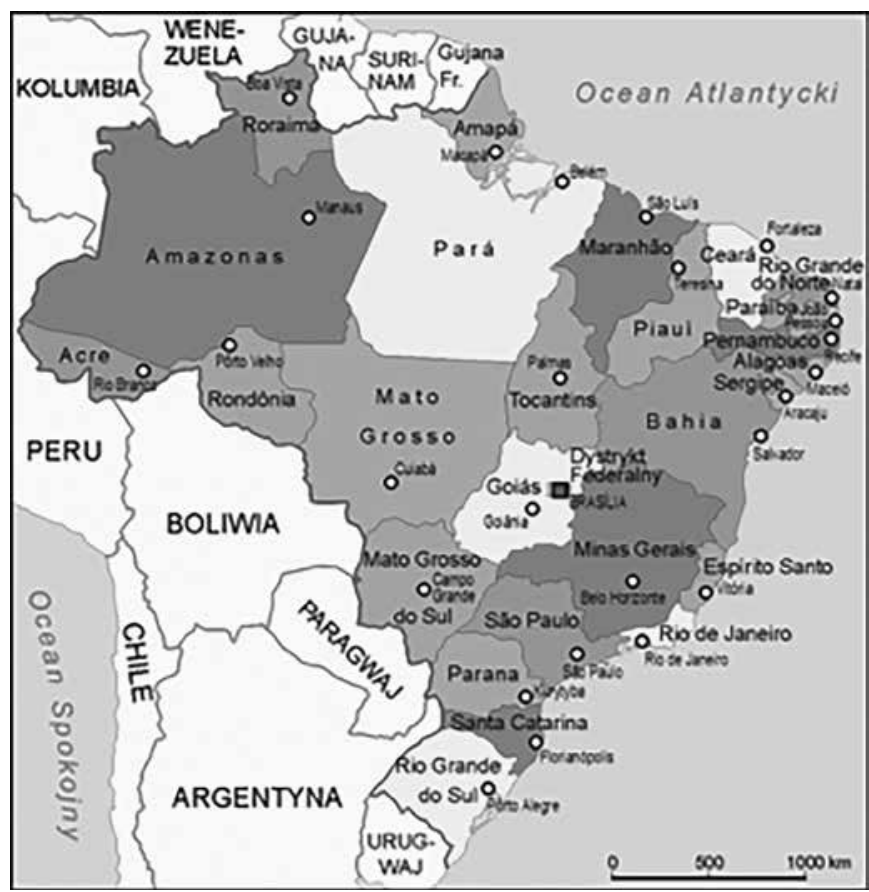

Źródło: https://commons.wikimedia.org/w/index.php?curid=8617326 [dostęp: 07.04.2018]

nowego stanu lub terytorium federalnego, za zgodą bezpośrednio zainteresowanej ludności (wyrażoną w drodze plebiscytu) oraz za zgodą Kongresu Narodowego (wyrażoną w ustawie uzupełniającej). Tworzenie, łączenie i podział gmin dokonują się na mocy ustawy stanowej, w terminie określonym w federalnej ustawie uzupełniającej (co wymaga uprzedniej konsultacji), w formie plebiscytu wśród ludności zainteresowanych gmin, po ogłoszeniu studiów o zdolności gmin do funkcjonowania, przedstawionych i opublikowanych na zasadach określonych w ustawie.

Miasto. Pamięći Przyszłość 3/2 (2018) ISSN 2543-621X 41

\section{Konstytucje}

Konstytucja Republiki Federacyjnej Brazylii została uchwalona dnia 5 października 1988 r. i obowiązuje do dziś5. Jest drugą konstytucją Brazylii po tej z listopada 1937 r., nazywanej też „polską”, ponieważ została zainspirowana modelem Konstytucji Kwietniowej.

Przywołana konstytucja będzie stanowiła podstawę do przedmiotowej analizy ${ }^{6}$. Brazylijska ustawa zasadnicza stanowi obszerną regulację (nie dziwi to w krajach latynoamerykańskich, lecz nadal zaskakuje kraje europejskie).

5. Constituição República Federativa do Brasil: promulgada em 5 de outubro de 1988. - 29e ed., aktualizada e ampliada 2002 / Sao Paulo: Saraiva, 2002.

6. Pełne tłumaczenie aktu prawnego dostępne pod adresem: http://libr.sejm.gov.pl/tek01/txt/konst/brazylia.html. [dostęp: 07.04.2018]. 
Konstytucja liczy 250 artykułów (oznaczonych cyframi arabskimi, rzymskimi, literami, paragrafami - bez wyraźnego rozgraniczenia). Podzielona jest na tytuły, rozdziały, sekcje.

Dla porównania polska konstytucja7 składa się z 243 artykułów. Różnica na pozór niewielka, jednak należy zaznaczyć, że polskie przepisy są mniej rozbudowane, nie regulują szczegółowo wielu kwestii, jak czyni to brazylijska konstytucja.

Podstawowe zasady funkcjonowania Brazylii zostały określone w art. 1 konstytucji. „Federacyjna Republika Brazylii, utworzona z nierozerwalnej unii stanów, gmin i dystryktu federalnego, konstytuuje się w demokratyczne państwo prawne i ma za podstawy:

I. suwerenność;

II. obywatelstwo;

III. godność osoby ludzkiej;

IV. społeczne wartości pracy i wolnej inicjatywy; V. pluralizm polityczny".

Jak stanowi w końcowej części ów przepis, jest to „paragraf jedyny”, zaś „Wszelka władza pochodzi od ludu, który sprawuje ją za pośrednictwem wybranych przedstawicieli lub bezpośrednio, na zasadach określonych w niniejszej Konstytucji".

W Brazylii mamy do czynienia z trójpodziałem władzy, co zostało podkreślone już w art. 2: "Niezależnymi od siebie i zharmonizowanymi ze sobą władzami Unii są: władza ustawodawcza, władza wykonawcza i władza sądownicza". Cele, jakie stawia sobie Brazylia jako państwo, to m.in. budowa społeczeństwa wolnego,

7. Konstytucja Rzeczypospolitej Polskiej z dnia 2 kwietnia 1997 r. uchwalona przez Zgromadzenie Narodowe w dniu 2 kwietnia 1997 r., przyjęta przez Naród w referendum konstytucyjnym w dniu 25 maja 1997 r., podpisana przez Prezydenta Rzeczypospolitej Polskiej w dniu 16 lipca 1997 r. (Dz.U. Nr 78, poz. 483 z późn. zm.). sprawiedliwego i solidarnego, zapewnienie rozwoju narodowego, zlikwidowanie ubóstwa i marginalizacji oraz zmniejszenie nierówności społecznych i regionalnych, popieranie dobra wszystkich bez uprzedzeń związanych z pochodzeniem, rasą, płcią, kolorem skóry, wiekiem i wszelkimi innymi formami dyskryminacji.

\section{Uwagi wstępne do analizy porównawczej samorządu terytorialnego obu państw}

Przed rozpoczęciem właściwej analizy ustroju brazylijskiego samorządu terytorialnego, należy przywołać art. 23 brazylijskiej konstytucji, który stanowi o kompetencjach wspólnych państwa i samorządu. Zgodnie z nim do kompetencji wspólnych Unii, stanów, dystryktu federalnego i gmin przynależą:

I. dbanie o przestrzeganie konstytucji i ustaw oraz o zachowanie instytucji demokratycznych, a także ochrona mienia publicznego;

II. dbanie o zdrowie i pomoc społeczną, o ochronę i gwarancje dla osób upośledzonych;

III. ochrona dokumentów, dzieł i innych dóbr o wartości historycznej, artystycznej i kulturowej, zabytków, wartościowych krajobrazów naturalnych i miejsc o wartości archeologicznej;

IV. zapobieganie nielegalnemu wywozowi, niszczeniu i wynaturzeniu dzieł sztuki i innych dóbr o wartości historycznej, artystycznej i kulturowej;

V. zapewnianie środków dostępu do kultury, edukacji i nauki;

Miasto. Pamięć i Przyszłość 3/2 (2018) ISSN 2543-621X 
VI . ochrona środowiska naturalnego i zwalczanie zanieczyszczenia we wszystkich jego przejawach;

VII. ochrona lasów, fauny i flory;

VIII.wspieranie produkcji rolnej i hodowlanej oraz organizowanie zaopatrzenia w żywność;

IX. wspieranie programów budowy mieszkań i polepszania warunków mieszkalnych oraz podstawowych warunków sanitarnych;

X. zwalczanie przyczyn ubóstwa i czynników marginalizacji poprzez popieranie integracji społecznej grup pokrzywdzonych;

$X I$. prowadzenie rejestru, kontrolowanie i nadzorowanie koncesji w zakresie prawa do poszukiwania i eksploatacji zasobów wodnych i mineralnych na danym terytorium;

XII. określanie i prowadzenie polityki edukacyjnej w dziedzinie bezpieczeństwa ruchu drogowego.

Jak stanowi w końcowej treści ów przepis, jest to „paragraf jedyny”, lecz „Ustawa uzupełniająca określa normy dotyczące współpracy między Unią a stanami, dystryktem federalnym i gminami, mając na uwadze równowagę rozwoju i dobrobyt na szczeblu narodowym".

Jednostki samorządu, tj. gmina i stan, cechują się samodzielnością, gwarantowaną konstytucyjnie. Unia nie interweniuje w sprawy stanów, chyba że w celu utrzymania integralności narodowej; odparcia obcej inwazji lub inwazji jednej jednostki federalnej na drugą; położenia kresu poważnemu zagrożeniu porządku publicznego; zapewnienia swobodnego działania każdej z władz jednostek federacji; reorganizacji finansów jednostki federacji; wymuszenia wykonania ustawy federalnej, nakazu lub orzeczenia sądowego; zapewnienia przestrzegania następujących zasad konstytucyjnych: republikańskiej formy rządów, systemu przedstawicielskiego i ustroju demokratycznego; praw osoby ludzkiej; autonomii gmin; kontroli rachunków administracji publicznej, bezpośredniej lub pośredniej; przeznaczenia na utrzymanie i rozwój oświaty oraz na publiczne działania i usługi zdrowotne wymaganego minimum dochodów uzyskanych z podatków stanowych, a także z przekazów.

Stan nie interweniuje w sprawy gmin znajdujących się na jego terytorium, ani Unia nie interweniuje w sprawy gmin znajdujących się na terytorium federalnym, chyba że nie jest płacony dług skonsolidowany przez dwa kolejne lata (z wyjątkiem przypadku siły wyższej); nie są przedstawiane wymagane rachunki, na zasadach określonych w ustawie; nie przeznacza się wymaganego minimum z dochodów gmin na utrzymanie i rozwój oświaty oraz na publiczne działania i usługi zdrowotne ${ }^{8}$.

Konstytucja Brazylii przywiązuje wielką wagę do kwestii interwencji, poświęcając jej osobny rozdział VI, w którym ustanawia jako formę prawną dekret o interwencji wydawany przez Kongres Narodowy na wniosek najwyższych władz sądowych lub Prokuratora Generalnego Unii (art. 36).

Administracja publiczna bezpośrednia i pośrednia którejkolwiek z władz Unii, stanów, dystryktu federalnego i gmin, przestrzega zasad
Miasto. Pamięć i Przyszłość 3/2 (2018) ISSN 2543-621X
8. Zob. art. 31 konstytucji Brazylii. 
legalizmu, bezstronności, moralności, jawności i skuteczności (art. 37). Podobna regulacja znajduje się w polskim porządku prawnym choćby przez odniesienie do zasady legalizmu z art. 7 konstytucji RP

Warto także wskazać na początku na ogólną dyrektywę konstytucyjną, która odnosi się do wszystkich jednostek samorządu w Brazylii i stanowi o zakazie dla Unii, stanów i gmin ustanawiania wyznań religijnych, tworzenia i subwencjonowania kościołów (za wyjątkiem współpracy w interesie publicznym na zasadach określonych w ustawie); nieuznawania mocy dowodowej dokumentów publicznych oraz różnicowania Brazylijczyków9 lub wprowadzania preferencji dla niektórych Brazylijczyków.

\section{Dystrykt federalny}

Prowadzona tu analiza nie jest poświęcona szczegółowemu opisowi dystryktu federalnego z uwagi na jego ustrojowy charakter w państwie.

9. Brazylijczykiem jest się z urodzenia albo z naturalizacji. Z urodzenia: urodzeni w Federacyjnej Republice Brazylii, nawet jeżeli ich rodzice są cudzoziemcami, pod warunkiem, że ci ostatni nie pozostają w służbie swojego kraju; urodzeni za granicą z ojca Brazylijczyka lub matki Brazylijki, jeżeli jedno z nich pozostaje w służbie Federacyjnej Republiki Brazylii; urodzeni za granicą z ojca Brazylijczyka lub matki Brazylijki, pod warunkiem, że zamieszkają w Federacyjnej Republice Brazylii i wybiorą, w którymkolwiek momencie, obywatelstwo brazylijskie. Z naturalizacji: ci, którzy na zasadach określonych w ustawie przyjęli obywatelstwo brazylijskie; od osób pochodzących z krajów portugalskojęzycznych wymaga się jedynie rocznego nieprzerwanego pobytu w Brazylii i nieskazitelnego charakteru; cudzoziemcy bez względu na posiadane obywatelstwo, którzy przebywają w Federacyjnej Republice Brazylii nieprzerwanie od ponad piętnastu lat i nie zostali skazani wyrokiem sądu, jeżeli wystąpią o nadanie im obywatelstwa brazylijskiego. Ponadto Portugalczycy stale zamieszkali w kraju korzystają z praw przysługujących Brazylijczykom, z wyjątkami przewidzianymi w konstytucji, pod warunkiem wzajemności dla Brazylijczyków. Żadna ustawa nie może różnicować Brazylijczyków z urodzenia i Brazylijczyków naturalizowanych, z wyjątkiem przypadków przewidzianych w konstytucji [art. 12 konstytucji].
Mimo to należy scharakteryzować główne elementy jego pozycji ustrojowej.

Ustrój dystryktu federalnego, którego podział na gminy został zakazany, określa ustawa organiczna, uchwalona w dwóch głosowaniach, w odstępie co najmniej dziesięciu dni i przyjęta większością dwóch trzecich członków Izby Ustawodawczej, która ją promulguje, przestrzegając przepisów ustanowionych w konstytucji. Dystryktowi federalnemu przyznaje się kompetencje ustawodawcze przysługujące stanom i gminom. Ma to swoje uzasadnienie praktyczne, z uwagi na to, że dystrykt jest wydzieloną terytorialnie jednostką.

\section{Domniemanie kompetencyjnej ma rzecz samorządu terytorialnego}

Porównanie ustroju samorządów obu państw warto zacząć od domniemania kompetencji. W Polsce, art. 164 ust. 3 Konstytucji stanowi, że „gmina wykonuje wszystkie zadania samorządu terytorialnego nie zastrzeżone dla innych jednostek samorządu terytorialnego". Przepis ten formułuje konstytucyjne domniemanie kompetencji na rzecz gminy. Podobny przepis odnajdziemy w art. 25 konstytucji brazylijskiej, jednak w jej przypadku mamy do czynienia z domniemaniem kompetencji na rzecz stanu. Jest ono wyrażone nieco odmiennie: „Dla stanów zastrzeżone są kompetencje, które nie zostały im zakazane w niniejszej konstytucji" (\$1).

\section{Stany}

Próba porównania pozycji ustrojowej stanów brazylijskich do polskich województw, a także

Miasto. Pamięć i Przyszłość 3/2 (2018) ISSN 2543-621X 
powiatów, nie przynosi żadnego skutku. W zasadzie okazuje się niemożliwa, zachęca jedynie do podstawowego badania prawnoporównawczego ograniczającego się opisu instytucji prawa różnych państw bez ich zestawienia.

Stany są największą jednostką podziału i samorządu terytorialnego. Do stanów należy przede wszystkim zapewnienie funkcjonowania lokalnych służb gazociągowych, bezpośrednio lub przez przyznawanie koncesji, na zasadach określonych w ustawie (art. 24). Stany, zgodnie z art. 25 konstytucji i na mocy ustawy uzupełniającej, mogą ustanawiać regiony metropolitalne, aglomeracje miejskie i mikroregiony, tworzone w formie zrzeszeń graniczących ze sobą gmin, w celu zintegrowania organizacji, planowania i wykonywania funkcji publicznych dotyczących interesu wspólnego.

W celu umożliwienia im zdolności wykonywania przypisanych zadań, konstytucja wyposaża stany w mienie określonego rodzaju zgodnie z art. 26:

I. wody powierzchniowe lub gruntowe, płynące, wypływające na powierzchnię i stojące, z wyjątkiem, w tym ostatnim przypadku na zasadach określonych w ustawie, wód pochodzących z prac prowadzonych przez Unię;

II. obszary wysp oceanicznych i przybrzeżnych, które do nich należą, z wyłączeniem tych, które należą do Unii, gmin lub osób trzecich;

III. wsypy na rzekach i jeziorach nie należące do Unii;

IV. nieużytki nienależące do Unii.

Miasto. Pamięć i Przyszłość 3/2 (2018) ISSN 2543-621X 45
Organami stanu są Zgromadzenie Ustawodawcze oraz gubernator. Liczba deputowanych do Zgromadzenia Ustawodawczego jest trzykrotnie większa niż liczba przedstawicieli stanu w Izbie Deputowanych. W przypadku, gdy wyliczona na tej podstawie liczba deputowanych do Zgromadzenia Ustawodawczego przekracza 36 osób, do tej liczby dodaje się tyle mandatów, o ile liczba przedstawicieli stanu w Izbie Deputowanych przekracza dwanaście. Kadencja trwa 4 lata, przy czym warto zaznaczyć, że w Brazylii wszystkie wybory odbywają się w pierwszą niedzielę października, zatem w praktyce kadencja wynosi nieco ponad cztery lata. Do kompetencji Zgromadzenia Ustawodawczego należy przede wszystkim stanowienie regulaminu wewnętrznego oraz przepisów dotyczących porządku i służb administracyjnych swojej kancelarii oraz obsadzanie poszczególnych stanowiskº.

Gubernatorzy są wybierani bezwzględną większością głosów także na 4-letnią kadencję (z prawem do jednej bezpośredniej reelekcji). Do ich kompetencji należy kierowanie administracją stanową oraz pełnienie funkcji reprezentatywnych ${ }^{11}$.

\section{Gminy}

O wiele większe pożytki badania komparatystycznego przynosi porównanie gmin polskich i brazylijskich.

Gminy w Brazylii rządzą się na zasadach określonych w ustawie organicznej, przyjętej w dwóch głosowaniach, w odstępie co najmniej dziesięciu dni, większością dwóch trzecich

10. Por. art. 27 konstytucji Brazylii. 11. Zob. art. 28 konstytucji Brazylii. 
członków Izby Gminnej, która ją promulguje. Ustawa ta musi być zgodna z zasadami wyrażonymi w konstytucji², w konstytucji danego stanu oraz przestrzegać zasad sformułowanych w art. 29 konstytucji:

I. bezpośrednie wybory burmistrza, wiceburmistrza i radnych, na czteroletnią kadencję, odbywają się równocześnie w całym kraju;

II. wybory burmistrza i wiceburmistrza odbywają się w pierwszą niedzielę października w roku poprzedzającym dzień upływu kadencji poprzedników;

III. objęcie urzędu przez burmistrza i wiceburmistrza ma miejsce pierwszego stycznia roku następującego po wyborach;

IV. liczba radnych jest proporcjonalna do liczby ludności13;

V. wynagrodzenie burmistrza, wiceburmistrza i sekretarzy gminnych określone jest w ustawie uchwalonej z inicjatywy Izby Gminnej;

VI. suma wydatków związanych z wynagrodzeniem radnych nie może wynosić więcej niż 5 proc. dochodów gminy; radnym przysługuje nietykalność za poglądy, wypowiedzi i sposób głosowania podczas sprawowania mandatu na obszarze gminy;

12. Podobnie jak w Polsce - wszystkie ustawy, w tym ustawy samorządowe muszą być zgodne z konstytucją.

13. Ograniczenia: nie mniej niż 9 i nie więcej niż 21 w gminach liczących mniej niż milion mieszkańców; nie mniej niż 33 i nie więcej niż 41 w gminach liczących ponad milion mieszkańców i mniej niż pięć milionów mieszkańców; nie mniej niż 42 i nie więcej niż 55 w gminach liczących ponad pięć milionów mieszkańców. Podobna konstrukcja jak w Polsce - liczba radnych zależna od liczby mieszkańców: 15 w gminach do 20 tys. mieszkańców, 21 w gminach do 50 tys. mieszkańców; 23 w gminach do 100 tys. mieszkańców; 25 w gminach do 200 tys. mieszkańców oraz po 3 na każde dalsze rozpoczęte 100 tys. mieszkańców, nie więcej jednak niż 45 radnych (art. 17 ustawy z dnia 8 marca 1990 r. o samorządzie gminnym - Dz. U. z 2018 r. poz. 994).

14. Ustawa z dnia 15 września 2000 r. o referendum lokalnym (Dz.U. z 2016 r. poz. 400 z późn. zm.)
VII. burmistrz ponosi odpowiedzialność przez Sądem Sprawiedliwości; inicjatywa ludowa w sprawie projektów ustaw o znaczeniu gminnym, miejskim lub dzielnicowym następuje w drodze wystąpienia co najmniej pięciu procent wyborców.

Przywołane zasady pochodzą wprost z konstytucji, zwraca uwagę zwłaszcza art. 29A regulujący wydatki gminy na wynagrodzenie radnych, podczas gdy w Polsce ustawa zasadnicza nie reguluje kwestii dochodów i wydatków tak szczegółowo. Odpowiednikiem brazylijskiej inicjatywy ludowej jest polskie referendum lokalne, regulowane odrębną ustawą ${ }^{14}$. W Brazylii inicjatywę może podjąć 5 proc. wyborców, dla porównania - w Polsce z wnioskiem o przeprowadzenie referendum z inicjatywy mieszkańców występuje inicjator referendum, którym może być grupa co najmniej 5 mieszkańców gminy, którym przysługuje czynne prawo wyborcze do rady gminy, przy czym w sprawie utworzenia, połączenia, podziału i zniesienia gminy oraz ustalenia jej granic grupa ta musi liczyć 15 mieszkańców; statutowa struktura partii politycznej, działająca na terenie danej gminy oraz organizacja społeczna, wyposażona w przymiot osobowości prawnej, działająca na terenie danej gminy.

Najwięcej podobieństw widać w zadaniach gmin, w Polsce określonych jako zadania własne. Art. 30 brazylijskiej konstytucji stanowi, że „Do kompetencji gmin należy:

I. stanowienie prawa w sprawach o znaczeniu lokalnym;

Miasto. Pamięć i Przyszłość 3/2 (2018) ISSN 2543-621X 
II. uzupełnianie ustawodawstwa federalnego i stanowego w sprawach dotyczących gmin;

III. ustanawianie i pobieranie danin w zakresie swoich kompetencji, a także dysponowanie wpływami, z zastrzeżeniem obowiązku prowadzenia księgowości i publikowania sprawozdań finansowych w terminach określonych w ustawie;

IV. tworzenie, organizowanie i znoszenie okręgów, przy poszanowaniu ustawodawstwa stanowego;

V. organizowanie i świadczenie, bezpośrednio lub przez wydawanie koncesji lub pozwoleń, usług publicznych o znaczeniu lokalnym, w tym usług komunikacji zbiorowej posiadającej zasadnicze znaczenie;

VI. realizowanie, przy technicznej i finansowej współpracy Unii i stanu, programów edukacji przedszkolnej i szkolnictwa podstawowego;

VII. świadczenie, przy technicznej i finansowej współpracy Unii i stanu, usług zdrowotnych dla ludności;

VIII. podejmowanie, w miarę potrzeby, działań na rzecz zapewnienia odpowiedniego ładu przestrzennego, poprzez planowanie i kontrolę użytkowania, podziału i zajmowania terenów miejskich;

IX. podejmowanie działań na rzecz ochrony lokalnych dóbr historyczno-kulturowych, zgodnie z ustawodawstwem federalnym i stanowym i pod kontrolą Unii i stanu.

I tak, odnosząc się do polskich regulacji, celem porównania, a w zasadzie wskazania na

Miasto. Pamięć i Przyszłość 3/2 (2018) ISSN 2543-621X podobieństwa - odpowiednikiem zadania z pkt I jest stanowienie aktów prawa miejscowego, tzn. aktów powszechnie obowiązujących, ale na danym terenie ${ }^{15}$, odpowiednikiem zadania z pkt III jest pobieranie podatków i opłat lokalnych (podatek od nieruchomości, podatek od środków transportowych, opłata targowa, opłata miejscowa, opłata uzdrowiskowa) ${ }^{16}$. Zadaniu z pkt VI odpowiada prowadzenie przez polskie gminy edukacji publicznej przedszkolnej, szkół podstawowych i gimnazjów", zadaniu z pkt VII - ochrona zdrowia'18, a zadaniu z pkt VIII - kształtowanie ładu przestrzennego, w tym ustanawianie miejscowego planu zagospodarowania przestrzennego ${ }^{19}$. Analogię do zadania z pkt IX można odnaleźć w nałożonym na polskie gminy zadaniu pielęgnowania kultury, w tym bibliotek gminnych i innych instytucji kultury oraz ochrony zabytków i opieki nad zabytkami20.

Powyższe porównanie napawa optymizmem, ponieważ widać wyraźnie, że nie tylko w Europie gmina ma na celu bycie blisko obywatela.

15. Zob. art. 40-42 ustawy o samorządzie gminnym.

16. W brazylijskich gminach są to podatki od nieruchomości zabudowanych i niezabudowanych, położonych w miastach; podatki z przenoszenia odpłatnie między żyjącymi, z jakiegokolwiek tytułu, rzeczy nieruchomych z natury lub z powodu ich przeznaczenia fizycznego, oraz praw rzeczowych na nieruchomościach, z wyjątkiem zabezpieczeń rzeczowych, a także od cesji praw do ich nabycia. Dla polskich gmin odniesieniem są przepisy ustawy z dnia 12 stycznia 1991 r. o podatkach i opatach lokalnych (Dz.U. z 2018 r. poz. 1445).

17. Zob. art. 7 ust. 1 pkt 8 ustawy o samorządzie gminnym i przepisy ustawy z dnia 14 grudnia 2016 r. - Prawo oświatowe (Dz.U. z 2018 r. poz. 996).

18. Zob. art. 7 ust. 1 pkt 5 ustawy o samorządzie gminnym.

19. Zob. art. 7 ust. 1 pkt 1 ustawy o samorządzie gminnym i przepisy ustawy z dnia 27 marca 2003 r. o planowaniu i zagospodarowaniu przestrzennym (Dz.U. z 2017 r. poz. 1073 z późn. zm.).

20. Zob. art. 7 ust. 1 pkt 9 ustawy o samorządzie gminnym i przepisy ustaw: z dnia 25 października 1991 r. o organizowaniu i prowadzeniu działalności kulturalnej (Dz.U. z 2017 r. poz. 862 z późn. zm.) oraz z dnia 23 lipca 2003 r. o ochronie zabytków i opiece nad zabytkami (Dz.U. z 2017 r. poz. 2187 z późn. zm.). 


\section{Finanse samorządowe}

Ciekawe wyniki badania porównawczego przynosi zestawienie przepisów regulujących dochody gmin w Polsce i Brazylii.

W polskich gminach najważniejszym źródłem dochodów własnych samorządu pozostają wpływy z podatków. Zgodnie z art. 4 ust. 1 pkt 1 ustawy o dochodach jednostek samorządu terytorialnego ${ }^{21}$ są to wpływy z: podatku od nieruchomości, rolnego, leśnego, od środków transportowych; dochodowego od osób fizycznych, opłacanego w formie karty podatkowej, od spadków i darowizn, od czynności cywilnoprawnych oraz wpływy z opłat: skarbowej, targowej, miejscowej, uzdrowiskowej i od posiadania psów, eksploatacyjnej22 oraz innych stanowiących dochody gminy, uiszczanych na podstawie odrębnych przepisów.

Z kolei do brazylijskich gmin należą wpływy z podatków Unii od dochodów i zysków wszelkiego rodzaju, pobieranych u źródła. Ponadto gminy otrzymują dochody z podatków od dochodów uzyskanych z jakiegokolwiek tytułu przez nie lub przez jednostki i fundacje przez nie tworzone i utrzymywane; 50 proc. wpływów z podatku Unii od własności ziemskiej na wsi, z tytułu nieruchomości w nich położonych; pięćdziesiąt procent wpływów z podatku stanowego od własności pojazdów silnikowych zarejestrowanych na ich terytorium; 25 proc. wpływów z podatków stanowych od czynności związanych z przepływem towarów i świadczeniem usług transportowych między stanami i między gminami oraz usług w dziedzinie łączności.

\section{Zakończenie}

Przedstawione informacje mogą wydawać się niepełne dla osoby znającej polskie regulacje prawne. Wynika to po pierwsze z odmiennego stanu prawnego - co oczywiste, ale także ze stanu posiadania ograniczonego pola badawczego. Można mieć jednak nadzieję, że przedstawione wyniki tego ograniczonego badania porównawczego, zachęcą do poznawania bliżej Brazylii, szczególnie pod względem jej samorządu terytorialnego.

\section{Literatura:}

https://histmag.org/Historia-Brazylii-10-dat-ktore-powinienes-znac-9603

- http://natemat.pl/176391,nawet-3-mln-mieszkancow-tego-regionu-w-brazylii-ma-polskie-korzenie-parana-mala-polska-za-oceanem

- https://www.brazil.org.za/states-of-brazil.html

- http://caipiroska.pl/category/stany-brazylii/

- http://www.df.gov.br/

- http://libr.sejm.gov.pl/tek01/txt/konst/brazylia. html

- https://commons.wikimedia.org/w/index. php?curid $=8617326$

- dezenovevinte.net

Miasto. Pamięć i Przyszłość 3/2 (2018) ISSN 2543-621X 